

Published in the Russian Federation

Oriental Studies (Previous Name: Bulletin of the Kalmyk Institute

for Humanities of the Russian Academy of Sciences)

Has been issued as a journal since 2008

ISSN: 2619-0990; E-ISSN: 2619-1008

Vol. 14, Is. 4, pp. 673-684, 2021

Journal homepage: https://kigiran.elpub.ru

УДК / UDC 94/47

DOI: 10.22162/2619-0990-2021-56-4-673-684

\title{
Борьба с эпидемиями в Казахстане в первой трети XX в.
}

\author{
Гульжаухар Какеновна Кокебаева ${ }^{1}$, Сабит Камытбекович Шилдебай
}

${ }^{1}$ Институт истории и этнологии им.Ч. Ч. Валиханова, Комитет науки Министерства образования и науки Республики Казахстан (д. 28, ул. Шевченко, 050010 Алматы, Казахстан) доктор исторических наук, профессор, заведующая отделом всемирной истории iD 0000-0002-6638-4663. E-mail: kokebayeva@gmail.com

${ }^{2}$ Центральный государственный архив Республики Казахстан (д. 39, просп. Абая, 050000 Алматы, Казахстан)

кандидат исторических наук, директор

iD 0000-0001-7110-2571. E-mail: S.Shildebai@gmail.com

(C) КалмНЦ РАН, 2021

(C) Кокебаева Г. К., Шилдебай С. К., 2021

Аннотация. Введение. Распространение опасных инфекционных болезней было постоянным спутником развития истории человечества. Пандемия, связанная с распространением новой коронавирусной инфекции COVID-19, подчеркивает важность изучения многолетнего опыта преодоления глобальных эпидемий. Цели и задачи исследования. В данной статье сделана попытка проанализировать проблему распространения инфекционных болезней в Казахстане и историю борьбы с эпидемией. История борьбы с эпидемиями в советском Казахстане охватывает большие пространственные и временные масштабы, поэтому хронологические рамки исследования ограничены периодом до начала 30-х гг. XX в. Материалы и методы. Материалами исследования являются документы из фондов Центрального государственного архива научно-технической документации Республики Казахстан и опубликованные отчеты государственных учреждений. При проведении исследования использован дескриптивный метод, который применяется при изучении проблем «реальной жизни». Дескриптивный метод позволил восстановить условия возникновения и распространения эпидемий в Казахстане и способов борьбы с ними. Применялся также историко-генетический метод, позволивший последовательно раскрыть сущность и динамику эпидемической ситуации в Казахстане в изучаемый период. Применение историко-сравнительного метода позволило выявить положительную динамику борьбы против распространения инфекционных болезней в советском Казахстане. Результаты. Проанализирована эпидемическая ситуация в Казахстане в дореволюционный и советский периоды. Исследована история образования и развития системы противоэпидемической защиты в советский период. Выявлены основные методы борьбы союзных и республиканских государственных учреждений с распространением инфекционных болезней. Сделаны 
вblводы относительно эффективности искоренения особо опасных инфекционных болезней путем вакцинации, медико-санитарного просвещения населения и других дополнительных мер.

Ключевые слова: эпидемия, инфекционные заболевания, вакцинация, общественное здравоохранение, эпидемическая ситуация, бактериологическая лаборатория, пастеризация

Благодарность. Исследование проведено в рамках реализации грантового проекта АР08957129 «История борьбы против инфекционных заболеваний и эпидемий в Казахстане (1920-1936)». Для цитирования: Кокебаева Г. К., Шилдебай С. К. Борьба с эпидемиями в Казахстане в первой трети XX в. // Oriental Studies. 2021. Т. 14. № 4. С. 673-684. DOI: 10.22162/2619-09902021-56-4-673-684

\title{
The Struggle against Epidemics in Kazakhstan, 1900s-1930s
}

\author{
Gulzhaukhar K. Kokebayeva ${ }^{1}$, Sabit K. Shildebai ${ }^{2}$
}

${ }^{1} \mathrm{Ch}$. Valikhanov Institute of History and Ethnology, Committee of Science, Ministry of Education and Science of the Republic of Kazakhstan (28, Shevchenko St., 050010 Almaty, Kazakhstan) Dr. Sc. (History), Professor, Head of World History Department

iD 0000-0002-6638-4663. E-mail: kokebayeva@gmail.com

${ }^{2}$ Central State Archive of the Republic of Kazakhstan (39, Abai Ave., 050000 Almaty, Kazakhstan) Cand. Sc. (History), Director

iD 0000-0001-7110-2571. E-mail: S.Shildebai@gmail.com

(C) KalmSC RAS, 2021

(C) Kokebayeva G. K., Shildebai S. K., 2021

Abstract. Introduction. Dangerous infectious diseases have always been part of human history. The pandemic associated with the spread of COVID-19 underscores the importance of studying experience of dealing with global epidemics. Research goals and objectives. This article attempts to analyze the problem of spread of infectious diseases in Kazakhstan and the history of dealing with epidemics. The history of combating epidemics in Soviet Kazakhstan covers a large spatial and temporal scale, so the chronological framework of the study is limited to the period up to the early 1930s. Materials and methods. Documents of the Central State Archive of Scientific and Technical Documentation of the Republic of Kazakhstan and published reports of the state institutions were used as the research sources. The narrative method selected as appropriate in approaching the issues of "real life" helped reconstruct the conditions that prompted the emergence and spread of epidemics in Kazakhstan, as well as examine the ways employed to combat them. The historical-genetic method was instrumental in shedding light on the essence and dynamics of the epidemic situation in Kazakhstan during the period in question, while the historical-comparative method was helpful in identifying the positive dynamics of the fight against infectious diseases in Soviet Kazakhstan. Results. The research was focused on the epidemic situations in Kazakhstan in the pre-revolutionary and Soviet periods. This involved a study of the formation and development of the system of anti-epidemic protection in the Soviet period, as well as of the main methods of combating infectious diseases employed by Soviet and republican government agencies. Conclusion. The research shows the effectiveness of vaccination, medical and sanitary education of the population involved, as well as of other additional measures in eradicating particularly dangerous infectious diseases.

Keywords: epidemic, infectious diseases, vaccination, public health, epidemic situation, bacteriological laboratory, pasteurization

Acknowledgements. The reported study was funded by grant AP08957129 'History of the Struggle against Infectious Diseases and Epidemics in Kazakhstan, 1920-1936'.

For citation: Kokebayeva G. K., Shildebai S. K. The Struggle against Epidemics in Kazakhstan, 1900s-1930s. Oriental Studies. 2021. Vol. 14 (4): 673-684. (In Russ.). DOI: 10.22162/2619-09902021-56-4-673-684 


\section{Введение}

Эпидемии, распространение среди людей чумы, оспы, холеры, тифа, малярии и других заразных болезней были самыми большими трагедиями в жизни человечества. Только к концу XX в. были достигнуты заметные успехи в борьбе с инфекционными болезнями, и по мере того, как мир добился прогресса в борьбе с ними, средняя продолжительность жизни человека стала намного больше. Последний известный случай оспы, поражавшей людей на протяжении многих веков, был диагностирован в 1977 г. в Сомали после почти двух десятилетий глобальной кампании вакцинации. Три года спустя ВОЗ официально объявила об искоренении оспы по всему миру. Однако вспышки новых инфекционных заболеваний, таких как «свиной грипп», ближневосточный респираторный синдром, гонконгский грипп, показали, что борьба с эпидемиями еще не закончилась. Пандемия, связанная со вспышкой новой вирусной инфекции COVID-19, унесшая жизни более трех миллионов человек, подчеркивает важность изучения многолетнего опыта преодоления глобальных эпидемий.

Историография истории эпидемий охватывает широкий круг научной литературы, в них рассматриваются различные аспекты возникновения, распространения и последствий эпидемий. Всеобщая история эпидемий, поразивших Европу, Америку, Африку и Азию с древних времен до наших дней, представлена в книге Дж. Хейса «Эпидемии и пандемии - их влияние на историю человечества» [Hays 2005]. Каждый очерк в книге объединяет биологическую и социальную информацию о крупных эпидемиях, которые оказали большое влияние на ход мировой истории.

В книге Дж. С. Лумиса содержится всесторонний обзор десяти самых влиятельных эпидемий в истории человечества. Автор рассматривает эпидемические заболевания как основную движущую силу в формировании нашего мира, показывает их важную роль в принятии решений о войнах, свержении империй, совершении крупных технологических скачков и даже в изменении генома человека [Loomis 2018].
Широкомасштабное исследование, которое выявляет связь между эпидемическими заболеваниями и социальными изменениями, представлено в книге Ф. М. Сноудена [Snowden 2019].

В своем мультидисциплинарном и сравнительном исследовании медицинской и социальной истории крупных эпидемий автор раскрывает влияние эпидемий на развитие медицины и состояние общественного здоровья, показывает, как они изменили историю искусства, религии и общественной мысли.

История распространения холеры в России исследована в работе американского ученого Дж. П. Дэвиса [Davis 2018]. В его монографии анализируются эпидемии холеры, происходившие в России в 18171917 гг. Автор на основе обширного архивного материала доказывает, что экологический подход врачей дореволюционной России к инфекционным болезням, их борьба с эпидемиями холеры, а также закладка основ системы общественного здравоохранения стали базой для образования советской государственной системы здравоохранения. Однако территориальные рамки исследования Дж. П. Дэвиса не охватывают Казахстан.

История эпидемий в России (чума 16601664 гг., восемь эпидемий холеры в XIX в., испанский грипп 1918-1919 гг., распространение тифа) и их последствия подробно изложены в книге К. Г. Васильева и А. Е. Сегала [Васильев, Сегал 1960].

Причины распространения инфекционных заболеваний на территории СССР и методы борьбы с эпидемиями рассматриваются в работах Е. И. Лотовой, Х. И. Идельчик, О. В. Барояна [Лотова, Идельчик 1967; Бароян 1968].

История борьбы с распространением инфекционных болезней в Казахстане остается малоизученной проблемой в отечественной историографии. Сведения о распространении инфекционных болезней и состоянии эпидемической ситуации на территории Казахстана можно найти в работах, посвященных истории развития системы 
здравоохранения [Чесноков 1946; Самарин 1958].

Как видно из историографического обзора, история эпидемий в Казахстане и методы борьбы с ними является малоизученным аспектом истории развития здравоохранения. В данной статье сделана попытка осмысления проблемы реализации государственной политики имперского и советского правительств в области борьбы с эпидемиями в Казахстане. История борьбы с эпидемиями в Казахстане охватывает большие территориальные и временные масштабы. Поэтому хронологические рамки исследования мы ограничили первой третью XX в. - периодом, особо трудным для Казахстана, бывшей окраины царской России с отсталой системой здравоохранения, перенесшей тяготы революционных событий и гражданской войны, пережившей принудительную коллективизацию и голод.

\section{Материалы и методы}

Источником исследования послужили материалы Центрального государственного архива научно-технической документации Республики Казахстан (далее ЦГА НТД РК) и опубликованные отчеты государственных учреждений, отражающие историю становления государственных структур, занимающихся профилактикой и лечением инфекционных заболеваний, статистику распространения основных инфекционных болезней в дореволюционном и советском Казахстане, меры по предотвращению эпидемий.

При проведении исследования использовался дескриптивный метод, который применяется при изучении проблем «реальной жизни». Дескриптивный метод позволяет восстановить условия возникновения и распространения эпидемий в Казахстане и способов борьбы с ними. Для анализа конкретного исторического материала использован историко-генетический метод, позволяющий последовательно раскрыть сущность и динамику эпидемической ситуации в Казахстане в изучаемый период. При анализе эволюции методов борьбы с эпидемией применен историко-сравнительный метод. Объективной основой для сравнения является то, что прошлое представляет собой повторяющийся в последующие периоды внутренне обусловленный процесс.
Эпидемическая ситуация в дореволюционном Казахстане

К началу XX в. во всех развитых странах появились национальные системы здравоохранения. Началось быстрое искоренение опасных инфекционных заболеваний, таких как чумы, холеры, оспы, скарлатины, было создано много различных вакцин. Произошло улучшение материального благополучия населения развитых стран, личная гигиена стала нормой. Однако все эти прогрессивные явления в основном происходили в центрах, а на периферии эпидемическая ситуация оставалась напряженной.

В дореволюционный период на территории Казахстана насчитывалось только 98 больниц, 96 амбулаторно-клинических учреждений, в которых работали 196 врачей. В Иргизском и Тургайском уездах один врачебный участок приходился на территорию в 85,5 тысяч км ${ }^{2}$, тем не менее, эти уезды считались хорошо обеспеченными в части медицинских услуг [Чесноков 1946: 4].

Кочевое население Казахстана не было охвачено специализированной медицинской помощью, что приводило к распространению разных инфекционных болезней.

Самой распространенной болезнью была малярия, коэффициент распространения в Казахстане был чуть выше, чем в Среднеазиатском крае в целом. Так, в 1911-1913 гг. в Средней Азии коэффициент заболеваемости малярией на 10 тысяч населения был 208, а в Казахстане - 216 [ЦГА НТД РК. Ф. 85. Оп. 1-6. Д. 189. Л. 18]. Среди регионов Казахстана самые высокие показатели заболеваемости малярией показывал Западный Казахстан [ЦГА НТД РК. Ф. 85. Оп. 1-6. Д. 60. Л. 16].

Как видно из таблицы 1 , заболеваемость малярией в Западном Казахстане показывает неуклонный рост с небольшими колебаниями. В этом регионе в 1914 г. смертность от малярии доходила до 12 \% к числу заболевших [Чесноков 1946: 5].

Территория Западного Казахстана представлена обширной Прикаспийской низменностью. Эта территория богата реками, болотами, озерами и заливными лугами; болота занимали около 650 тысяч гектаров земли; средняя относительная влажность воздуха составляет 45-70\%. Совокупность таких условий обсуловила высокий коэффициент заболеваемости ма- 
Таблица 1. Показатели заболеваемости малярией в Западном Казахстане в 1899-1916 гг. [Table 1. Malaria morbidity rate in Western Kazakhstan, 1899-1916]

\begin{tabular}{|l|l|l|l|l|l|}
\hline Годы & $\begin{array}{l}\text { Численность } \\
\text { заболевших }\end{array}$ & $\begin{array}{l}\text { Коэффициент } \\
\text { заболеваемости на } \\
10 \text { тысяч населения }\end{array}$ & Годы & $\begin{array}{l}\text { Численность } \\
\text { заболевших }\end{array}$ & $\begin{array}{l}\text { Коэффициент } \\
\text { заболеваемости на } \\
10 \text { тысяч населения }\end{array}$ \\
\hline 1899 & 18549 & 271,1 & 1908 & 20070 & 267,6 \\
\hline 1900 & 16361 & 236,7 & 1909 & 21488 & 275,2 \\
\hline 1901 & 15799 & 225,1 & 1910 & 26484 & 340,4 \\
\hline 1902 & 16064 & 226,2 & 1911 & 33735 & 421,6 \\
\hline 1903 & 17382 & 241,7 & 1912 & 33275 & 413,2 \\
\hline 1904 & 18496 & 253,7 & 1913 & 41728 & 510,1 \\
\hline 1905 & 16574 & 227,3 & 1914 & 49596 & 586,9 \\
\hline 1907 & 17888 & 245,0 & 1915 & 45447 & 524,1 \\
\hline
\end{tabular}

лярией населения в этом регионе. Кроме того, отсутствие медицинской помощи также способствовало широкому распространению малярии среди коренного населения региона. 51,3 \% населения данного региона жили в кочевых районах, 22,3\% — в полукочевых, $26 \%$ - в оседлых районах [ЦГА НТД РК. Ф. 85. Оп. 1-6. Д. 189. Л. 15]. Один врачебный участок в Западном Казахстане должен был обслуживать в среднем 49800 человек; на одного врача приходилось в среднем 2450 городских, 68450 сельских жителей [ЦГА НТД РК. Ф. 85. Оп. 1-6. Д. 60. Л. 22].

Казахские кочевники не были охвачены медицинской помощью вообще, небольшие лечебные учреждения находились только в городах. Так, в Акмолинской области, охватывающий 479200 квадратных верст ${ }^{1}$, имелось всего 9 лечебных заведений на 109 коек [Самарин 1958: 50].

В начале XX в. такие инфекционные заболевания, как оспа, корь, дифтерия и коклюш, были широко распространены, поскольку эффективных мер борьбы с ними было мало, коэффициент смертности был высоким. Много жизней в Казахстане уносили чума, оспа, тиф и другие инфекционные болезни. В 1904-1905 гг. во время эпидемии в Среднеазиатском пустынном природном очаге чумы болезнь распространилась и на территорию Казахстана, расположенную на левом берегу реки Жайык. В 1905-1906 гг. в Нарынском регионе была зарегистрирована вспышка чумы, где забо-

1 Верста - русская мера длины, равная 1,06 км. лели 659 чел., из которых 621 умер. Вспышки чумы среди населения Казахстана были отмечены также в 1907, 1910-1914, 1918, 1928 гг. [Сагиев 2020б: 7, 20].

В 1910 г. в Акмолинской области смертность от оспы составляла 18,6 \% от числа заболевших, от дифтерии - 19,3\%, от брюшного тифа - $10 \%$, от сыпного тифа $10,4 \%$, от дизентерии - 12,5, от скарлатины - 11,4\%. [Самарин 1958: 53]. В 1907 г. в Семипалатинской области вспыхнула эпидемия холеры, занесенная, по официальным сообщениям, крестьянами-переселенцами [Самарин 1958: 60]. В течение двух месяцев заболели 86 чел., из которых 44 умерли. В 1913 г. в Семиреченской области корь, дифтерия, скарлатина регистрировались на всех участках, в некоторых местах эти заболевания принимали характер эпидемии [Самарин 1958: 65].

В период Первой мировой войны в лагерях для военнопленных в России случались эпидемии тифа, которые иногда распространялись на прилегающие территории. Так, в 1915 г. в Западном Казахстане была эпидемия тифа с 1129 случаями заражения и 115 смертельными исходами [Patterson 1993: 373].

В последний год войны началась эпидемия так называемого испанского гриппа, в 1918 г. эпидемия бушевала в Европе, однако, где началась вспышка, было неясно. Некоторые медики обвиняли китайских рабочих, которых привозили во Францию для рытья траншей, испанская медицинская комиссия объявила, что болезнь возникла в русском Туркестане. Большинство стран 
мира приписали это Испании, так как за несколько месяцев до этого эпидемия гриппа захлестнула эту страну, поразив восемь миллионов человек [Persico 1976: 28].

Однако все эти версии не были доказаны. Многие правительства прибегли к мерам изоляции, карантину и дезинфекции, однако глобальное передвижение войск сводило на нет усилия по сдерживанию распространения инфекции. В то время не было вакцины от гриппа и еще не были разработаны антибиотики для лечения вторичных бактериальных инфекций. Испанский грипп получил распространение в западных и северо-западных регионах РСФСР.

Становление системы противоэпидемической зашиты в Казахстане в советский период

Инфекционные заболевания, имеющие высокую степень интенсивности распространения, были одной из сложных проблем в стране. Во время революции и гражданской войны, эпидемии испанского гриппа, различных видов тифа и голода не было возможности организовать планомерную систематическую медицинскую помощь. Отчеты медицинских учреждений этого периода содержат только констатацию фактов распространения инфекционных болезней и отсутствия возможности оказания медицинской помощи.

Созданный в 1920 г. Народный комиссариат здравоохранения РСФСР разрабатывал планы организации медицинской помощи и профилактики эпидемий, однако в ситуации послевоенной разрухи и хаоса эти планы не были осуществлены.

В 1920-е гг. уровень распространения инфекционных болезней на территории Киргизской АССР (официальное название Казахстана до 1925 г.) был очень высоким, к тому же сравнение данных за 1921, 1922, 1923 гг. не характеризует улучшение динамики коэффициента заболеваемости населения автономной республики. Так, в 1921 г. в Киргизской АССР коэффициент заболеваемости на 1000 чел. населения был 72,8; в 1922 г. - 83,2; в 1923 г. - 70,2. В 1923 г. в Киргизской АССР всего было 285857 инфекционных больных, из них 82268 чел. находились в губернских городах, 203589 чел. - в уездах [Соловьев 1924: 59, 67].
В 1920 г. среди зарегистрированных больных в Киргизской АССР было больных цингой -6186 , оспой -2575 , скарлатиной - 1589 , корью - 1887 , коклюшем 2 138, брюшным тифом - 16 591, сыпным тифом - 31435 , возвратным сыпным тифом - 28 982, сыпным тифом неизвестного происхождения - 6271 , дизентерией 11 447, азиатской холерой - 30 006, сибирской язвой - 225, малярией - 35572 [Отчет народного комиссариата 1921: 20-21]. Эпидемии этого периода в основном были связаны с холерой и малярией.

Как известно, в 1899-1923 гг. в мире происходила шестая пандемия холеры. вспышка этой инфекции началась в Индии в результате употребления зараженных продуктов питания и воды. Это последняя волна болезни, которая с начала 1800-х гг. периодически вызывала пандемии. Болезнь распространилась также на Россию и некоторые районы Ближнего Востока и Северной Африки, в конечном итоге убивая сотни тысяч человек, особенно много погибших было в Индии и России [Claeson, Waldman, 2021].

В 1921 г. в России число заболевших холерой людей достигло 207000 чел., из которых 44,8 \% погибли [Rosenberg 1962: 3]. В конце июня 1921 г. эпидемия холеры из Самары распространилась на территорию Казахстана, и до конца августа заболели 13789 чел., холера унесла жизнь 5706 чел. [Отчет народного комиссариата 1921: 20-21].

В 1922 г. из 8158 человек, заболевших холерой, умерли 4 733. Подавляющее большинство инфицированных холерой были сельскими жителями (6 394 чел.), из них умерли 59 \%. Холера в этот период была одной из самых опасных и смертоносных эпидемий [Отчет Совета 1922: 259]. Крупная эпидемия холеры в 1922 г. произошла в Семиреченской области, где из 3395 заболевших 2533 умерли (74,6 \%) [Сагиев 2020a: 10].

Для систематической борьбы с инфекционными заболеваниями и эпидемиями в декабре 1921 г. при Народном комиссариате здравоохранения РСФСР была создана Центральная чрезвычайная санитарная комиссия, которая отвечала за мобилизацию всех сил и средств на борьбу с эпидемиями. 
Такая же комиссия была создана и в Киргизской АССР, в состав которой вошли народный комиссар здравоохранения республики, уполномоченный ВЧК и начальник военно-санитарного отдела народного комиссариата здравоохранения. При губернских исполнительных комитетах также были созданы чрезвычайные санитарные комиссии для текущего контроля и разъяснения мер борьбы с эпидемией (эти комиссии в документах, переписке по проблемам ликвидации очагов эпидемии называются «санитарными тройками») [ЦГА НТД РК. Ф. 82. Оп. 1. Д. 79. Л. 8].

Распространение малярии, брюшного тифа, холеры и других инфекционных заболеваний было связано не только с плохими социальными условиями жизни населения, но и неблагоприятными условиями окружающей среды, отсутствием доступа к чистой питьевой воде. Кроме того, распространение каждой из этих инфекционных болезней в Казахстане имело свои специфические причины. Так, заболевание городского населения брюшным тифом было связано с антисанитарией, плохим водоснабжением, а причиной его стремительного распространения стала скученность населения в быстрорастущих городах. В общественных столовых, где питались работники различных промышленных предприятий и учреждений, имела место чрезвычайная загрязненность посуды из-за отсутствия системы снабжения горячей водой и централизованной канализации. В сельских местностях распространению болезней способствовали также и такие дополнительные факторы, как интенсивное передвижение населения и частые откочевки.

Распространению сыпного тифа в Казахстане способствовали передвижение городского населения в переполненных транспортных средствах в условиях антисанитарии, неустроенность и скученность населения в неблагоустроенных домах, отсутствие бань в некоторых частях областных городов. Все перечисленные причины были характерны для большинства городов и сел страны после гражданской войны и иностранной интервенции. Однако эти факторы многократно усиливались в Казахстане в связи с массовым голодом 1921-1922 гг.
В начале июня 1923 г. проходил Третий всекиргизский съезд отделов здравоохранения, на котором наряду с основными вопросами (отчет Наркома здравоохранения, вопрос о состоянии медико-санитарного дела и т. п.) обсуждались меры борьбы с распространением инфекционных болезней на территории республики, в том числе с чумой в Букеевской и Уральской губерниях. В своем отчете нарком здравоохранения М. С. Шамов, отмечая плачевное состояние медико-санитарного дела в Казахстане и сложности задач, стоящих перед наркоматом, говорил: «Здоровая питьевая вода, охрана жилищ, почвы, воздуха, охрана труда и т. д. отсутствовала даже в губернских городах, более или менее благоустроенных, не говоря уже о кибитке и землянке киргиза, куда не проникал ни один луч санитарного света. Нужно было создать кадр медперсонала, в котором наш край нуждался даже в мирное время. Нужно было создать противочумную организацию, пришедшую в упадок во время империалистической войны и совсем уничтоженную во время гражданской войны... Задачи трудные, задачи непосильные, но требующие немедленного разрешения, ибо эпидемия 19-20-21 годов, косившая направо и налево целые поселки, станицы и аулы, не была еще изжита, и нужно было ожидать вспышки ее в 22-м году. Не менее серьезна была опасность со стороны холеры. Можно было ожидать вспышки чумы в Букеевской и Уральской губерниях» [Труды 1923: 6].

В 1923 г. в Букеевской и Уральской губерниях чумой заболели 122 чел., из них 119 умерли, в том числе полностью все члены 13 семейств, состоящих из 67 человек. $\mathrm{B}$ очагах эпидемии работали несколько отрядов в составе 9 врачей (в том числе три бактериолога), 9 фельдшеров и 22 санитара, были приняты карантинные меры [Труды 1923: 65-72].

Однако отдаленность жилищ, охваченных болезнью, позднее оповещение медицинских учреждений о вспышке, отсутствие транспорта и крайне медленное передвижение отрядов медицинского персонала затрудняли работу по ликвидации очагов эпидемии.

Напомним, самой распространенной в Казахстане болезнью была малярия, количество заболевших ею составляло 73,9 \% от 
всех инфекционных больных; на 1000 чел. в губернских городах республики приходилось 238 больных малярией, в уездах 390 , когда в среднем в СССР было 51,9 [Соловьев 1924: 64].

12 мая 1924 г. было принято постановление Совета Народных Комиссаров РСФСР «О мероприятиях по борьбе с малярией». Местные власти должны были «оказывать всяческое содействие организации дела борьбы с малярией на местах, привлекая к этой работе заинтересованные ведомства, профессиональные организации и широкие массы населения, в частности: а) провести по указаниям местных здравотделов неотложные и осуществимые мероприятия по оздоровлению почвы и по осушению болот, прудов, других водоемов, способствующих развитию малярии...» [Действия и распоряжения 1924: 77].

Рост заболеваемости населения малярией наблюдался и в последующие годы, в статистике распространения малярии лидирующее положение занял Западный Казахстан. Если в 1926 г. по СССР в целом коэффициент заболеваемости малярией на 10 тыс. населения был 312,9 , по Казахской АССР в целом - 259, то в Западном Казахстане он составил 493,7; в 1927 г. по СССР - 249,9, по Казахской АССР - 233,8, по Западному Казахстану - 349,7; в 1928 г. по СССР 219,9 , по Казахской АССР - 163,5, по Западному Казахстану - 324 [ЦГА НТД РК. Ф. 85. Оп. 1-6. Д. 60. Л. 18].

Высокий процент заболеваемости малярией населения Западного Казахстана связан не только с природными факторами (наличие большого количества рек и других водоемов), но и слабостью системы здравоохранения: здесь на одного врача приходилось 1140 чел. городского населения, 68450 чел. сельского населения [ЦГА НТД РК Ф. 85. Оп. 1-6. Д. 60. Л. 22].

В плане борьбы с эпидемиями большое значение имеет точный бактериологический диагноз инфекционных заболеваний, однако из-за отсутствия в Казахстане санитарно-бактериологических лабораторий, вся борьба с эпидемиями сводилась к принятию карантинных мер и ликвидации очагов болезни, а изучение характера инфекционных болезней, выявление очагов и причин распространения почти не было. Как известно, в распространении брюшно- го тифа и дифтерита определенную роль играют бациллоносители, поэтому санитарно-бактериологические лаборатории должны были вести определенные обследования с целью их обнаружения.

При возникновении чумы, малярии и некоторых других инфекционных болезней источниками заражения могут служить животные, насекомые, вода, пищевые продукты. Определив источник заражения, санитарно-бактериологические лаборатории могли бы разработать методику успешной борьбы с эпидемией.

Наркомат здравоохранения Киргизской АССР в 1922 г. создал в Оренбурге Краевую химико-бактериологическую лабораторию, которая должна была заниматься вопросами санитарии и эпидемиологии в республике. Однако малочисленный штат и отсутствие некоторых нужных специалистов затрудняли работу лаборатории. В июле на базе этой лаборатории был создан Краевой санитарно-бактериологический институт (впоследствии он стал Краевым санитарно-бактериологическим институтом имени КазЦИК).

К началу 1926 г. в Институте имелись бактериологическое, химическое, клинико-диагностическое, сывороточное, серологическое отделения, малярийная и пастеровская станции, были также и отделы, занимавшиеся проблемами вакцинации. Санитарно-бактериологический институт финансировался Народным комиссариатом здравоохранения Киргизской АССР, имел право также получать денежные дотации от Красного Креста и других учреждений.

В 1926-1928 гг. проводились профилактические работы: сотрудники энтомологического кабинета обследовали наличие насекомых, вызывающих малярию и другие инфекционные болезни, в 20370 различных водоемах, 108 жилых и нежилых помещениях города Алматы и его окрестностей [ЦГА НТД РК. Ф. 85. Оп. 1-6. Д. 22. Л. 1112].

В 1929-1930 гг. Народный комиссариат здравоохранения КазАССР организовал семь экспедиций в районы строительства железной дороги Турксиб и другие части Казахстана. Или-Каратальская, Балхашская, Переселенческая, Алма-Атинская аульно-сельская, Бальнеологическая и другие экспедиции проводили санитарно-гигиенические и эпидемиологические исследования 
районов переселения, а также районов, в которых предусматривалось создание совхозов, специализировавшихся на выращивании риса; обследовали территорию Прибалхашья, Копал-Арасанский и Алматинский минеральные источники. Уничтожение болезнетворных насекомых и борьба с вредителями также способствовали снижению заболеваемости. Противочумная экспедиция обследовала грызунов в пограничных с Китаем местностях Алматинского и Семипалатинского округов [ЦГА НТД РК. Ф. 85. Оп. 1-6. Д. 26 а. Л. 26].

Бактериологическая и пастеровская станции занимались выработкой профилактических вакцин и лечебных сывороток: республика была полностью обеспечена оспенным детритом; в 1926 г. были изготовлены 20 литров дивакцины, 12 литров стафилококковой вакцины, 5 литров стрептококковой вакцины. Больные в большинстве случаев обследовались только для диагностических целей, из-за нехватки санитарных врачей очень редко проводились повторные анализы в постлечебный период.

Однако проведенная профилактическая работа и содействие в лечении больных дали определенные положительные результаты. Так, в 1926 г. через пастеровскую станцию прошло 175 больных, случаев смертельного исхода не было [Штибен 1927: 111, 113].

Однако эти частичные профилактические меры не смогли предотвратить распространение некоторых инфекционных болезней в республике. Статистика заболеваемости инфекционными болезнями населения Казахстана в конце 1920-х - начале 1930-х гг. показывает неуклонный рост болезней в период выполнения первого пятилетнего плана. Так, количество заболевших брюшным тифом в 1929 г. было 5 413, в 1930 г. - 6114,1931 г. — 12 201, в 1932 г. 13 119; число заболевших сыпным тифом с 288 в 1930 г. выросло до 37980 в 1932 г.

Массовая вакцинация началась в 1931 г., но более полная вакцинация городского населения была произведена только в 1933 г., сельские местности все еще не были охвачены вакцинацией [ЦГА НТД РК. Ф. 85. Оп. 1-6. Д. 51. Л. 3, 5, 7].

Тревожные звонки поступали также и от врачей, обслуживавших рабочих на строительстве Туркестанско-Сибирской железной дороги. Только на одном из участков линии строительства было зарегистрировано 115 заболеваний брюшным тифом, в Илийской больнице лечили 35 и в Айнабулаке - 53 чел., остальные больные оставались в своих бараках, палатках и юртах.

В Илийске больные лежали в сарае во дворе амбулатории в своей одежде, без постельных принадлежностей, без питания и ухода; больные с различными диагнозами лежали вместе, так, рабочий, заболевший малярией, мог заболеть, уже лежа в больнице, и брюшным тифом [Шейгал 1929: 5].

Сотрудники Санитарно-бактериологического института выезжали на участки вдоль линии Турксиба, проведенные бактериологические и серологические исследования на 7-м участке подтвердили диагноз брюшного тифа у 35 больных, в крови у 9 чел. была обнаружена культура бацилл брюшного тифа, у 29 чел. реакция Видаля дала положительный результат, что позволило констатировать эпидемию брюшного тифа. На 6-м участке были обнаружены несколько человек, зараженных брюшным тифом и малярией, у одного больного была положительная реакция Видаля с бациллами брюшного тифа 1/50 и с микробами мальтийской лихорадки 1/200. После этого было решено открыть в Талдыкургане и Сарканде Пастеровские прививочные пункты, сделать прививки всем рабочим Северной и Южной частей Турксиба [ЦГА НТД РК. Ф. 85. Оп. 1-6. Д. 52. Л. 19-20].

В декабре 1930 г. были получены известия о распространении сыпного тифа в городе Алматы, эта проблема была обсуждена на экстренном заседании Чрезвычайной Комиссии по борьбе с эпидемиями. Было решено выделить помещения для изоляции больных, быстро подключить больницы в водопроводную сеть, открыть дополнительные прачечные в больницах, форсировать банное строительство в городе, обязать руководство Турксиба выделить для пассажиров помещения на вокзалах [ЦГА НТД РК. Ф. 85. Оп. 1-6. Д. 56. Л. 53-54].

Местные органы власти также предпринимали профилактические меры: домовладельцев и арендаторов, заведующих общежитиями и общественными помещениями в городах, обязали произвести очистку выгребных и помойных ям и дворов от мусора, очистку улиц рядом с их усадьбами, улучшить санитарное состояние общежитий 
и постоялых дворов [ЦГА НТД РК. Ф. 85. Оп. 1-6. Д. 56. Л. 32].

Перемещение населения из сельских местностей на крупные промышленные стройки в городах, сопровождавшее усиленную индустриализацию, привело к перенаселенности в плохих жилищах, где отсутствовала система общественного водоснабжения и удаления отходов. Эти условия привели к повторным вспышкам холеры, дизентерии, туберкулеза, брюшного тифа, гриппа и малярии. Быстрый рост заболеваемости инфекционными болезнями населения Казахстана в этот период был связан не только со слабостью профилактических мер, но и с массовым голодом, охватившим всю территорию республики в 1932-1933 гг.

\section{Заключение}

Распространение инфекционных болезней в первой трети XX в. и борьба с ними привели многие страны мира к необходимости создания тщательно продуманной глобальной системы здравоохранения, состоящей из различных сетей организаций, обслуживающих население. Из-за отсутствия подобной системы здравоохранения в дореволюционном Казахстане борьба с инфекционными заболеваниями носила эпизодический характер, средства борьбы с эпидемическими заболеваниями были очень ограничены, не хватало и хорошо обученных и опытных врачей, фельдшеров и медицинских сестер.

После образования СССР, несмотря на трудности восстановления экономики, разрушенной гражданской войной, предотвращение эпидемий считалось одной из важных задач государства. Союзные, республиканские и местные органы здравоохранения добились определенного прогресса в деятельности по профилактике

\section{Источники}

ЦГА НТД РК — Центральный государственный архив научно-технической документации Республики Казахстан.

\section{Литература}

Бароян 1968 - Бароян О. В. Итоги полувековой борьбы с инфекциями в СССР и некоторые актуальные вопросы современной эпидемиологии. М.: Медицина, 1968. $303 \mathrm{c}$. заболеваний, включая обследование источников инфекций и организацию лечения больных. Наибольшую проблему создавали инфекционные заболевания, такие как сыпной тиф, брюшной тиф, холера, оспа, дизентерия и другие болезни, распространяющиеся через пищеварительный тракт. Заболеваемость ими была связана не только с плохими условиями жизни населения, но и плохой личной гигиеной и гигиеной окружающей среды, а также отсутствием доступа к чистой питьевой воде. Чтобы предотвратить распространение инфекционных болезней, за счет государственных средств были профинансированы важные мероприятия в области санитарии, а также программы вакцинации; республика была полностью обеспечена оспенным детритом. Значительную роль в борьбе с эпидемиями сыграли также научно-исследовательские институты, которые выявляли природные очаги заражения, источники и механизмы передачи инфекции. Была организована вакцинация населения от опасных инфекционных болезней. Вакцины защищают не только здоровье иммунизированного человека, но и здоровье общества. Если уровень вакцинации достаточно высок, передача инфекционных заболеваний в сообществе прекращается, а это означает, что даже те, кто не вакцинирован, получают защиту.

Кроме вакцинации, человечество нашло много дополнительных стратегий против различных возбудителей инфекционных болезней. Антибиотики, пастеризация, чистая питьевая вода, медико-санитарное просвещение населения, борьба с бедностью и недоеданием, улучшение жилищных и санитарно-гигиенических условий, другие достижения в области общественного здравоохранения были и остаются решающими факторами в борьбе с эпидемиями.

\section{Sources}

Central State Archive of Scientific and Technical Documents of the Republic of Kazakhstan.

Васильев, Сегал 1960 - Васильев К. Г., Сегал A. Е. История эпидемий в России / ред. А. И. Метелкин. М.: Гос. изд-во мед. литер-ры, 1960. 395 с.

Действия и распоряжения 1924 - Действия и распоряжения правительства РСФСР // 
Вестник здравоохранения Киргизии и Казахстана. 1924. № 1-2 (4-5). С. 77-78.

Лотова, Идельчик 1967 - Лотова Е. И., Идельчик $Х$. И. Борьба с инфекционными болезнями в СССР (1917-1967): очерки истории. М.: Медицина, 1967. 432 с.

Отчет народного комиссариата 1921 - Отчет народного комиссариата здравоохранения КССР 2-му всекиргизскому съезду советов. Оренбург: Тип. Губсовнархоза, 1921. 60 с.

Отчет Совета 1922 - Отчет Совета труда и обороны Киргизской Советской Социалистической Республики за апрель - сентябрь 1922 года: Экономическое издание СТО и Госплана КССР. Оренбург: Тип. ГСНХ, $1922.309 \mathrm{c}$.

Сагиев 2020а - Холера в Республике Казахстан: пространственная и временная характеристики (атлас-справочник) / ред. 3. А. Сагиев. Алматы: Қазақ университеті, 2020. 164 с.

Сагиев $2020 б$ - Хронологический атлас-справочник заболеваний чумой на территории Среднеазиатского пустынного природного очага чумы в пределах Республики Казахстан / ред. 3. А. Сагиев. Алматы: Қазақ университеті, 2020. 276 с.

Самарин 1958 - Самарин Р. И. Очерки истории здравоохранения Казахстана. Алма-Ата: Казгосиздат, 1958. 163 с.

Соловьев 1924 - Соловьев А. В. Заразная заболеваемость в Кирреспублике за 1923 г. (Краткий статистический отчет) // Вестник здравоохранения Киргизии и Казахстана. 1924. № 1-2 (4-5). С. 58-67.

Труды 1923 - Труды 3-го Всекиргизского съезда здравотделов. Оренбург: Советская степь, 1923. $237 \mathrm{c}$.

Чесноков 1946 - Чесноков С. А. Здравоохране-

\section{References}

Baroyan O. V. The Fifty Year Long Struggle against Infections in the USSR: Outcomes and Some Topical Issues of Contemporary Epidemiology. Moscow: Meditsina, 1968. 303 p. (In Russ.)

Chesnokov S. A. Public Health Services in Kazakhstan. Alma-Ata: Kazogiz, 1946. 72 p. (In Russ.)

Claeson M., Waldman R. "Cholera”. Encyclopedia Britannica, Invalid Date, https://www.britannica.com/science/cholera. Accessed 16 December 2021

Davis J. P. Russia in the Time of Cholera: Disease under Romanovs and Soviets. London; New York: IB Tauris (Bloomsbury Publishing), 2018. 336 p. (In Eng.) ние в Казахстане. Алма-Ата: Казогиз, 1946. $72 \mathrm{c}$.

Шейгал 1929 - Шейгал Я. С. Медпомощь на Южтурксибе // Здравоохранение в Казахстане. 1929. № 3. С. 4-7.

Штибен 1927 - Штибен В. Д. Отчет о деятельности Краевого Санитарно-Бактериологического института Казнаркомздрава имени КазЦИК'а (Кзыл-Орда) // Вестник здравоохранения Казахстана. 1927. № 1 (16). С. 107131.

Claeson, Waldman, 2021 - Claeson M., Waldman R. "Cholera". Encyclopedia Britannica, Invalid Date, https://www.britannica.com/science/ cholera. Accessed 16 December 2021.

Davis 2018 - Davis J. P. Russia in the Time of Cholera: Disease under Romanovs and Soviets. London; New York: IB Tauris (Bloomsbury Publishing), 2018. 336 p.

Hays 2005 - Hays J. Epidemics and Pandemics: Their Impacts on Human History. Santa Barbara: ABC-CLIO, 2005. 526 p.

Loomis 2018 - Loomis J. S. Epidemics: The Impact of Germs and Their Power over Humanity. Santa Barbara: Praeger, 2018. 323 p.

Patterson 1993 - Patterson K. D. Typhys and its control in Russia, 1870-1940 // Medical History. 1993. No. 37. P. 361-381.

Persico 1976 - Persico J. E. The Great Spanish Flu Epidemic of 1918 // American Heritage. 1976. Vol. 27. Is. 4. P. 28-31.

Rosenberg 1962 - Rosenberg Ch. E. The Cholera Years: The United States in 1832, 1849, and 1866. Chicago: The University of Chicago Press, 1962. 257 p.

Snowden 2019 - Snowden F. M. Epidemics and Society: From the Black Death to the Present. New Haven, CT: Yale University Press, 2019. $600 \mathrm{p}$.

Hays J. Epidemics and Pandemics: Their Impacts on Human History. Santa Barbara: ABC-CLIO, 2005. 526 p. (In Eng.)

Kyrgyz SSR Council of Labor and Defense: Report, April - September1922. Orenburg: Tip. Orenburg Governorate Council of National Economy, 1922. 309 p. (In Russ.)

Kyrgyz SSR People's Healthcare Commissariat: Report Delivered at the Second Kyrgyz National Congress of Soviets. Orenburg: Orenburg Governorate Council of National Economy, 1921. 60 p. (In Russ.)

Loomis J. S. Epidemics: The Impact of Germs and Their Power over Humanity. Santa Barbara: Praeger, 2018. 323 p. (In Eng.) 
Lotova E. I., Idelchik Kh. I. The Soviet Struggle against Infectious Diseases, 1917-1967: Historical Essays. Moscow: Meditsina, 1967. 432 p. (In Russ.)

Patterson K. D. Typhus and its control in Russia, 1870-1940. Medical History. 1993. No. 37. Pp. 361-381. (In Eng.)

Persico J. E. The Great Spanish Flu Epidemic of 1918. American Heritage. 1976. Vol. 27. No. 4. Pp. 28-31. (In Eng.)

Rosenberg Ch. E. The Cholera Years: The United States in 1832, 1849, and 1866. Chicago: The University of Chicago Press, 1962. 257 p. (In Eng.)

RSFSR Government: deeds and decrees. Vestnik zdravookhraneniya Kirgizii $i$ Kazakhstana. 1924. No. 1-2 (4-5). Pp. 77-78. (In Russ.)

Sagiev Z. A. (ed.) Cholera in the Republic of Kazakhstan: Areal and Time Characteristics. Reference atlas. Almaty: Kazakh National University, 2020. 164 p. (In Russ.)

Sagiev Z. A. (ed.) Plague Morbidity within the Central Asian Desert Disease Area (Republic of Kazakhstan): A Chronological Reference Atlas. Almaty: Kazakh National University, 2020. 276 p. (In Russ.)
Samarin R. I. Public Health System of Kazakhstan: Historical Essays. Alma-Ata: Kazakhstan State Publ. House, 1958. 163 p. (In Russ.)

Sheygal Ya. S. Southern section of the Turkestan-Siberia Railway: medical services revisited. Zdravookhranenie v Kazakhstane. 1929. No. 3. Pp. 4-7. (In Russ.)

Shtiben V. D. Sanitary and Bacteriology Research Institute of Kazakh People's Healthcare Commissariat (Kyzylorda): Activity Report. Vestnik zdravookhraneniya Kazakhstana. 1927. No. 1 (16). Pp. 107-131. (In Russ.)

Snowden F. M. Epidemics and Society: From the Black Death to the Present. New Haven, CT: Yale University Press, 2019. 600 p. (In Eng.)

Solovyov A. V. Infectious morbidity in the Kyrgyz SSR, 1923: a brief statistical report. Vestnik zdravookhraneniya Kirgizii i Kazakhstana. 1924. No. 1-2 (4-5). Pp. 58-67. (In Russ.)

The Third Kyrgyz National Congress of Public Health Departments: Proceedings. Orenburg: Sovetskaya Step, 1923. 237 p. (In Russ.)

Vasilyev K. G., Segal A. E. A History of Epidemics in Russia. A. Metelkin (ed.). Moscow: State Publ. House of Medical Literature, 1960. 395 p. (In Russ.) 